\author{
Ivan Pukšar* \\ Silvija Vitner Marković* \\ Sabina Ajdinović**
}

\title{
ZAŠTITA ZDRAVLJA ZAPOSLENIKA U TURISTIČKOM SEKTORU
}

\begin{abstract}
Sažetak
Zaposlenici u turističkom sektoru snažno su izloženi riziku obolijevanja od zaraznih bolesti, posebno oni koji su u direktnom kontaktu s gostima iz cijelog svijeta poput hotelskog osoblja, turističkih vodiča, zrakoplovnog osoblja i slično. Rizik je tim veći što do prijenosa zarazne bolesti može doći kada još simptomi zaraze kod osoba nisu manifestirani. Također, zaposlenici u turističkom sektoru mogu biti izravni prenositelji zaraznih bolesti u određenom trenutku, a da toga nisu ni svjesni. Turistička i druga putovanja $u$ takvom slučaju mogu poslužiti kao izvrstan medij za prenošenje zaraznih bolesti u vrlo kratkom vremenu iz jednog područja u drugo, s jednog kontinenta na drugi. Zaposlenici turističkog sektora trebaju znati zaraznu bolest prepoznati u ranoj fazi te promptno pristupiti poduzimanju zaštitnih mjera. Predmet ovog rada podrazumijeva vrlo aktualnu problematiku koja se odnosi na zaštitu zdravlja zaposlenika u turističkom sektoru s naglaskom na zaštitu od zaraznih bolesti. Cilj je rada analizirati suvremene mehanizme zaštite zdravlja turističkih djelatnika od obolijevanja od zaraznih bolesti u svijetu, a time i u Republici Hrvatskoj.
\end{abstract}

Ključne riječi: zaposlenici u turizmu, zarazne bolesti, mehanizmi zaštite zdravlja, zdravstveni rizik

\section{Uvod}

Svjetski turizam je u 2019. zabilježio rekordne brojke te je prema podacima Svjetske turističke organizacije iz turističkih motiva 2019. globalno putovalo više od 1,5 milijardi osoba. Broj turističkih dolazaka u svijetu 2019. raste stopom od $4 \%$ u odnosu na prethodnu 2018. (UNWTO, 2020). Pandemija COVID-19 prouzročila je pad broja

* Ivan Pukšar, mag. oec., Coned turizam d.o.o., Jastrebarsko, ivan.puksar7@gmail.com

** dr. sc. Silvija Vitner Marković, prof. visoke škole, Veleučilište u Karlovcu, silvija.vitner@vuka.hr

*** Sabina Ajdinović, studentica, Veleučilište u Karlovcu, sajdinovi@vuka.hr 
međunarodnih turističkih dolazaka u svijetu za 22 \% tijekom prvog tromjesečja 2020. Kriza u svijetu uzrokovana pandemijom mogla bi dovesti do smanjenja fizičkog turističkog prometa 2020. između $60 \%$ i $80 \%$ u usporedbi s podacima iz 2019. To dovodi $\mathrm{u}$ opasnost milijune radnih mjesta u turističkom sektoru te prijeti usporavanjem napretka u postizanju ciljeva održivog razvoja (UNWTO, 2020).

Dobra svjetska prometna povezanost omogućila je brzi prijenos ljudi i roba s jednog kontinenta na drugi, ali i pospješila transmisiju virusa Covid-19 iz središta zaraze diljem svijeta u vrlo kratkom razdoblju i to u većem obimu od onog kojeg je uopće bilo moguće u početku pandemije predvidjeti. Zbog toga smo svjesni činjenice da turizam, a posebno promet, pospješuju brzi prijenos zaraznih bolesti na udaljenosti koje su prije stotinjak godina bile nezamislive. U prijenosu mogućeg virusa sudjeluju, kako sami putnici, tako i profesionalno osoblje, koji možda i nemaju simptome bolesti u datom trenutku, ali mogu djelovati kao potencijalni prijenosnici zaraze.

Republika Hrvatska je kao receptivna turistička zemlja izrazito izložena takvom riziku transmisije zaraznih bolesti. Svi oni koji sudjeluju u prijevozu turista dolaze u kontakt, ili u turističkom odredištu, ili tijekom kružnog putovanja. Turistički djelatnici prvi ostvaruju kontakt s turistima koji su stigli iz potencijalno kriznih područja te se prijenos potencijalne zaraze može ostvariti neposredno. Intencija autora ovog rada nije stigmatizacija turizma zbog potencijalnih zdravstvenih rizika, već naglašavanje osjetljivosti i izloženosti turističkih djelatnika mogućoj zarazi.

Slikovito se može prikazati osjetljivost i izloženost turističkih djelatnika potencijalnoj zarazi kroz više primjera potvrđenih slučajeva. Prema preporuci Svjetske zdravstvene organizacije (UNWHO) i drugih nadležnih tijela, svim je objektima kojima se putnici kreću na svom putu već propisana zaštita koja se treba provesti kako bi se rizik zaraze sveo na najmanju moguću razinu. S istom namjerom Republika Hrvatska je posredstvom Hrvatskog zavoda za javno zdravstvo (HZJZ, 2020) na vrijeme pripremila detaljne upute za sve djelatnike, prijevozna sredstva, smještajne i druge ugostiteljske objekte te ih javno distribuirala. Važna je fizička udaljenost među putnicima u prijevoznim sredstvima. Broj i raspored putnika u sjedalima takav je da omogućava propisani razmak između njih. Npr. putnici sjede naizmjence na sasvim lijevom i sasvim desnom sjedalu (HZJZ, 2020). Strogo pridržavanje propisanih mjera pomoglo je zaštiti zdravlja zaposlenika u turizmu. Primjena propisanih mjera izazvala je dodatne troškove u poslovanju, najčešće na teret prijevoznika i smještajnih ugostiteljskih objekata. Smanjen je i maksimalno raspoloživ prijevozni kapacitet. Vrlo slične preporuke vrijede u različitim oblicima prijevoza. Potrebno je istaknuti da se pravila i preporuke često mijenjaju sukladno iskustvima u praćenju razvoja bolesti i pokušaja da štete za nacionalno gospodarstvo budu što je moguće manje. 


\section{Kontakti osoblja s putnicima u zračnim lukama i u zrakoplovu}

U najvećem broju slučajeva prvi kontakt između putnika i turističkih djelatnika (pod istim pojmom smatraju se i djelatnici u svim oblicima prijevoza) dolazi u zračnoj luci i to u kontaktu između putnikove prtljage i osoba u zračnoj luci. Posebnim propisima postavljeni su strogi standardi koji nalažu socijalnu distancu u fizičkim razmacima između osoba već pri dolasku u zračnu luku, obavezno nošenje zaštitnih maski i rukavica tijekom boravka u zračnoj luci, moguće beskontaktne prijave na let kod onih prijevoznika čija tehnologija to omogućava, prolazak putnika kroz posebne dezinfekcijske komore (u trajanju od oko 40 sekundi) radi dekontaminacije, jednako kao i posebni postupci za prtljagu koji će onemogućiti mogući proboj virusa. Način sjedenja u zrakoplovu umanjuje mogućnost bližih kontakata, svi putnici obavezni su nositi zaštitne maske tijekom leta, kao i osoblje. Zabranjena je konzumacija hrane i pića u zrakoplovu te se korištenje sanitarnog čvora u zrakoplovu omogućava samo u iznimnim situacijama. Iako su mjere naizgled vrlo stroge, putnici zbog vlastite sigurnosti relativno lako prihvaćaju takvo ponašanje i prilagođavaju se okolnostima novog načina putovanja.

Različite zrakoplovne kompanije primjenjuju različite propisane mjere. Dio njih mjeri temperaturu osoblju i putnicima prije ulaska u zrakoplov, dijelom i uz pomoć termalnih kamera. Naprednije kompanije omogućuju tzv. biometrijski check in koji isključuje bilo kakav fizički dodir. Putnici trebaju u zračnu luku stići i do četiri sata prije leta, a gotovo sve kompanije izbacuju korištenje srednjeg sjedala, osim za obitelji. Ukrcaj putnika odrađuje se na način da u zrakoplov prvo ulaze putnici u zadnjem redu, zabranjuje se unos osobne prtljage osim nužne, poput laptopa i manjih elektronskih aparata. Neke kompanije naprave brzi krvni test putnika, hrana i piće servira se u unaprijed pakiranim kutijama kako bi se smanjio broj kontakta s osobljem, zabranjeno je korištenje novina te bilo kakvih pomagala koje bi moglo koristiti više putnika tijekom leta.

Posebna pažnja posvećana je ventilaciji u zrakoplovu. Naglašava se primjena vertikalnih smjerova ventilacije, a umanjuje se ili kompletno blokira horizontalna ventilacija. Temeljita dezinfekcija kabinskog prostora i svih dijelova zrakoplova prije i poslije leta je dakako conditio sine qua non. Zrakopovne kompanije svjesne su da njihova budućnost ovisi upravo o primjeni takvih mjera, sve do prestanka pandemije, međutim pojedine mjere zaštite i preventive ostat će i duže vrijeme u primjeni.

Neke zrakoplovne kompanije razmišljaju i o aktivnoj primjeni tzv. propusnice immunity passport koju bi imali putnici koji su preboljeli Covid-19 i imaju antitijela u organizmu. Utoliko bi antitijela štitila organizam od ponovne infekcije (Puckett, 2020). Međutim, s obzirom na to da medicina trenutačno dobro ne poznaje virus, 
ne postoji jamstvo da se putnik ne bi mogao razboljeti i drugi put te je trenutačno ta mogućnost sporna. Pregledno su navedene sve mjere koje generalno imaju pozitivne efekte na zaštitu djelatnika u prijevozu, kao i turizmu.

\subsection{Kontakti putnika i osoblja po dolasku u odredišnu zračnu luku}

Po dolasku putnika u odredišnu zračnu luku slijede također brojni procesi koji će umanjiti rizik mogućeg prijenosa virusa, kako s putnika na osoblje, tako i s prtljage na osoblje koje će s njom doći u kontakt. Prtljaga koja se nalazi u prtljažnom prostoru na vrlo niskim temperaturama od minus 30 ili 50 stupnjeva Celzijusa ne može biti značajno kontaminirana, ali oprez je svejedno nužan, prije svega zbog toga što prtljaga do putnika koji je preuzma na pokretnoj traci putuje transporterima i bude u kontaktu s osobljem koje radi na iskrcaju prtljage pa je dodatna dekontaminacija svakako poželjna.

Sljedeći kontakt između putnika koji je stigao zrakoplovom odnosi se na osoblje zračne luke u graničnoj kontroli i carini, ukoliko zračna luka nema automatsku provjeru putovnica koja je beskontaktna. Nakon što putnik i njegova prtljaga prođu i tu fazu u putovanju, slijedi kontakt s osobljem i/ili predstavnicima turističke agencije koja dočekuje gosta ili djelatnicima u rent a car službi i slično. Preporuča se korištenje zaštitnih maski i rukavica, i kod osoblja, i kod putnika.

U kontaktu s prtljagom može biti osoblje koje radi na ispomoći oko ukrcaja prtljage u prijevozno sredstvo. U najvećem broju slučajeva to je upravo vozač autobusa. Važno je da ima što manje osobnih kontakata s putnikom, što pretpostavlja da je prtljaga valjano označena (oznakom u kojem će hotelu biti iskrcana te tko je vlasnik prtljage) što će pomoći pri dolasku gosta u smještajni objekt i dostavi prtljage do njegove sobe ili apartmana.

Turistički pratitelji, voditelji putovanja ili turistički vodiči također su izloženi osobnim kontaktima s putnicima, pa je korištenje zaštitne maske, vlastitog mikrofona ili drugog beskontaktnog uređaja za komunikaciju s putnicima presudna. U prijevoznom sredstvu potrebno je osigurati socijalnu distancu putnika. Isto se manifestira u maksimalno dozvoljenom broju putnika u autobusu, načinu sjedenja, međusobnoj udaljenosti putnika i slično. Potrebno je korištenje zaštitnih maski i rukavica tijekom vožnje autobusom, kao i dezinfekcija ruku prije ulaska u autobus. Tamo gdje je to moguće poželjna je i dezinfekcija obuće prije ulaska u prijevozno sredstvo.

Turističke vodiče u pravilu gosti za dobro obavljen posao nagrađuju gotovinom, tzv. bakšišom. Takav običaj nije poželjan u uvjetima pandemije pa turističke agencije trebaju voditi računa o tome da takvu uslugu, kao što je to primjer na programima krstarenja, unaprijed zaračunaju putniku koji bi time bio oslobođen nagrađivanja turističkog vodiča prilikom završetka razgleda, izleta ili putovanja. Kako bi se smanjio opticaj kontaminiranog gotovog novca u svakom obliku, iznos bakšiša za dobro obavljen posao uračuna se u cijenu usluge turističkog vodiča. 


\section{Kontakt gosta i osoblja u hotelskim prostorima}

Hotelijeri imaju obavezu postupati odgovorno prilikom pružanja usluga gostima što uključuje standard razborite brige. Menadžment hotela u svakodnevnom poslovanju ima zadaću predviđati potencijalno neizvjesne situacije te preventivno djelovati kako bi izbjegao moguće opasnosti po pitanju ugrožavanja sigurnosti i zdravlja gostiju (Hayes i Ninemeier, 2005). Upravo prema standardu razborite brige menadžment hotela, između ostalog, prevenira i u svrhu sprečavanja širenja zaraznih bolesti.

Preporuke epidemiologa govore u prilog da osobnog kontakta treba biti što je moguće manje između gosta i osoblja u hotelu te da se sve hotelske rezervacije, kao i prijave gostiju, trebaju odraditi unaprijed i na daljinu kako bi se što je moguće više spriječio osobni kontakt. Ukoliko je on neophodan, pregrade od pleksiglasa smatraju se primjerenim rješenjem. Kartice soba koje će se aktivirati putem mobitela, automatska odjava gosta iz hotela putem monitora u hotelskoj sobi, beskontaktni način plaćanja i slično epidemiološke su mjere koje pridonose manjem riziku od prijenosa zarazne bolesti.

Hrvatski zavod za javno zadravstvo izdao je detaljna uputstva koja se trebaju primijeniti u smještajnim objektima u Republici Hrvatskoj. Veliki hotelski lanci počinju primjenjivati tehnologiju koju koriste bolnice za dezinfekciju posebnim strojevima i uređajima. Među posebne metode ubraja se i primjena ultraljubičastih zraka za dezinfekciju hotelskih kartica / ključeva te svih uređaja koje učestalo koristi više osoba. Uklanja se iz društvenih prostora hotela namještaj koji bi poticao na okupljanje i druženje više osoba istovremeno te se ograničava broj osoba koje mogu odjednom boraviti u zatvorenom prostoru.

Iz hotelske ponude uklanja se all inclusive usluga, buffet doručak, samoposluživanje izložene hrane i svi se obroci unaprijed serviraju (u posebnim pakiranjima s dostavom u sobu, ukoliko to gost želi). Hoteli uvode evidenciju dolaska osoblja na posao uz obavezno mjerenje tjelesne temperature, dvosmjenski rad s obaveznom dezinfekcijom prostora između dviju smjena te kompletnu dezinfekciju opreme koju koriste gosti smještajnog objekta.

\section{Zaključak}

Iako se svijet u zadnjih desetak i više godina susretao s raznim oblicima zaraznih bolesti i epidemija (npr. svinjska gripa, ptičja gripa, ebola, virus zika i sl.), ništa slično pandemiji Covid-19 nije se dogodilo još od pandemije španjolske gripe dvadesetih godina prošlog stoljeća. Brzom razvoju pandemije pogodovala je dobra prometna povezanost između kontinenata te ubrzani razvoj turizma na globalnoj razini koji je poticao bliske kontakte između putnika iz raznih dijelova svijeta. Pritom su zaposleni 
u turizmu bili prvi izloženi potencijalnom djelovanju virusa. Svjetska zdravstvena organizacija, kao i nacionalni stožeri zaduženi za sprečavanje širenja virusa, donosili su brojne preporuke i upustva te time pomogli, između ostalog, zaposlenima u turističkom sektoru da se primjenom zaštitnih mjera umanji rizik obolijevanja. Preventivno djelovanje u svrhu zaštite zdravlja turista, ali i zaposlenih u turizmu nužna je pretpostavka zaštite zdravlja svjetskog stanovništva uopće.

\section{Literatura}

1. Chang, R. How to Clean Your Luggage After the Trip Because Germs. Conde Nast Traveler. https://www.cntraveler.com/story/how-to-clean-your luggage? 20. svibnja 2020.

2. Hayes, D. i Ninemeier, J. 2005. Upravljanje hotelskim poslovanjem. Zagreb: Mplus.

3. Hrvatski zavod za javno zdravstvo: preporuke. https://www.hzjz.hr/sluzba-epidemiologija-zarazne-bolesti/koronavirus-najnovije-preporuke/. 20. svibnja 2020.

4. Marriot Hotels - Cleaning. Conde Nast Traveler.

5. https://www.cntraveler.com/story/marriott-hotels-new-cleaning-routine-involves-sanitizingsprayersanduvlight?utm_source $=$ nl\&utm_brand $=$ cnt\&utm_mailing $=C N T$ _ COVID_042620\&utmcampai. 20. svibnja 2020.

6. Puckett, J. Could Airlines Require Immunity Passports for Travelers to Fly Again? Conde Nast Traveler.

7. https://www.cntraveler.com/story/could-airlines-require-immunity-passports-for-travelers-to-fly-again. 20. svibnja 2020.

8. Udruženje hrvatskih putničkih agencija: upute.

9. http://www.uhpa.hr/clanak/hzjz-upute-za-ugostiteljske-objekte-35047. 20. svibnja 2020.

10. UNWTO World Tourism Barometer and Statistical Annex. https://www.unwto.org/ world-tourism-barometer-n18-january-2020. 20. svibnja 2020. 


\title{
Health protection of employees in the tourism sector
}

\begin{abstract}
Employees in the tourism sector are strongly exposed to the risk of contracting infectious diseases, especially those who are in direct contact with tourists from around the world such as hotel staff, tour guides, etc. The risk is high because the transmission of infectious diseases can occur when symptoms of infection are not manifested. Also, employees in the tourism sector can be direct carriers of infectious diseases at a given time without even being aware of it. Tourists and travelers can serve as an excellent medium for the transmission of infectious diseases in a very short time from one area to another, from one continent to another. Employees in the tourism sector should know how to recognize an infectious disease at an early stage, and promptly start taking protective measures. The subject of this paper is the protection of employees' health in the tourism sector with an emphasis on protection against infectious diseases. The aim of this paper is to analyze modern mechanisms for protecting the health of employees in the tourism sector from infectious diseases in the world, and thus in the Republic of Croatia.
\end{abstract}

Key words: employees in the tourism sector, infectious diseases, health protection mechanisms, health risk 